\title{
Comparative Wood Anatomy of Stem and Root in Korean-grown Yellow-poplar (Liriodendron tulipipfera L.)*1
}

\author{
Mi Rim Lee*2 and Young Geun Eom²†
}

\begin{abstract}
This study was carried out to offer basic information on the wood anatomy of domestic yellow-poplar (Liriodendron tulipifera L.), a new plantation species selected by Korea Forest Service as one of the promising hardwood and bioenergy sources of the future, through comparison of stem wood with root wood in the qualitative and quantitative features. In the qualitative anatomical features, growth rings were distinct in stem wood but relatively less distinct in root wood. And stem wood appeared to have pores in radial multiples of 2 to 5 , sometimes clusters but root wood to have pores in radial multiples of 2 to 3 , rarely clusters. And numbers of bars in scalariform perforation plates were somewhat numerous in vessel elements of root wood than in those of stem wood. Interestingly, on the other hand, more extraneous materials in the wood rays of tap root than in those of lateral root and stem were confirmed in the chemical composition analyses. In the quantitative anatomical features, pore densities were significantly greater but vessel elements were considerably narrower in stem wood than in root wood. Vessel elements and wood fibers of root wood were considerably longer than those of stem wood. Rays were somewhat more numerous in stem wood than in root wood, and only ray heights of stem wood were more or less greater in cell numbers but both ray heights and widths of stem wood were lower in dimension than those of root wood. The anatomical differences between stem wood and root wood were thought to be associated with different growth environments between the stem above ground and the root below ground.
\end{abstract}

Keywords : Liriodendron tulipifera L. yellow-poplar, root wood, stem wood, qualitative and quantitative anatomical features

\section{INTRODUCTION}

The process of primary tissue development before the formation of cambium is different between stem and root but that of secondary tissue development after the formation of cambium is identical to each other (Lee, 1985; Fahn,
1990). But root adopts the stem structure when exposed out of ground due to the reaction to light and stem takes on root structure when buried in the ground due to the lack of the same photomorhpogenetic stimulus. Thus, anatomical differences between them are recognizable within a tree because the growth environment is dif-

*1 Received on September 9, 2011; accepted on September 15, 2011

*2 Department of Forest Products \& Biotechnology, College of Forest Science, Kookmin University, Seoul 136-702, Korea

† Corresponding author : Young Geun Eom (e-mail: eom@kookmin.ac.kr) 
ferent between root below ground and stem above ground (Timell 1986; Schweingruber et al. 2006; Bowyer et al. 2007). Despite coexistence of root with stem within a tree, however, extensive studies have not been concentrated on the root wood or comparison of this root wood with stem wood.

In earlier studies, some anatomical differences were found between stem wood and root wood. Rao et al. (1989) found in the anatomical comparison of aerial root wood and stem wood of Sonneratia caseolaris that pore densities, i.e. numbers of pores or vessels per square millimeter, and maximum sizes of intervascular pits were significantly larger but average tangential diameters and lengths of vessel elements were considerably smaller in root wood. Druses and stellate crystals in vessel elements were reported to be frequent in root wood but absent in stem wood, whereas tyloses and gummy deposits in vessel elements to be frequent in stem wood but absent in root wood. Also, intercellular spaces between fibers were identified only in root wood. Stokke and Manwiller (1994) in Quercus velutina found the highest proportions of vessel elements, rays, axial parenchyma cells plus vasicentric tracheids, and fibers in the wood of branch, root, stem, and stem and branch, respectively. Ewers et al. (1997) in comparing vessel element diameters of root wood and stem wood noted significantly wider vessel elements in root wood than in stem wood for Fabaceae trees and shrubs and vice versa for Fabaceae lianas. Also, they found vessel elements of stem wood to be significantly wider in climbing species than in non-climbing species but those of root wood not to be significantly different between growth forms. Machado et al. (1997) observed the quantitative and qualitative differences between root wood and stem wood in Styrax camporum. Quantitatively, root wood was disclosed to have wider and shorter vessel elements, lower vessel frequencies, and wider rays than stem wood. Qualitatively, vessel elements with simple perforation plates and vestured pits, and septate libriform fibers were found in root wood but vessel elements with multiple perforation plates and non-vestured pits, and non-septate fiber tracheids in stem wood. In the comparison of stem and root anatomy of the shrub Phlomis fruticosa, Psaras and Sofroniou (2004) indicated that tangential diameters of vessel elements in root wood were approximately twice those in stem wood, and pores were usually arranged in tangential bands in stem wood but were usually solitary, partly radial multiples of 2 in root wood. Palhares et al. (2007) identified more parenchyma cells and thin-walled fibers in root wood than in stem wood as well as starch grains in root wood but not in stem wood in Brosimum gaudichaudii. They also found rays of root wood to be 1- to 5 -seriate but those of root wood to be mostly 1to 2-seriate and rarely 3-seriate. In the study on structural variations in root and stem wood of Styrax from Atlantic forest and Cerrado, Machado et al. (2007) observed the anatomical differences between habitat and species as well as between root wood and stem wood within a single species. Vessel elements were found to be wider in tangential diameter in stem wood than in root wood for Atlantic forest species and vice versa for Cerrado species.

This paper offers an anatomical comparison between stem wood and root wood in Koreangrown yellow-poplar (Liriodendron tulipifera L.), a species hitherto not studied in this respect.

\section{MATERIALS and METHODS}

\subsection{Materials}

In present study, two 5-year old yellow-pop- 


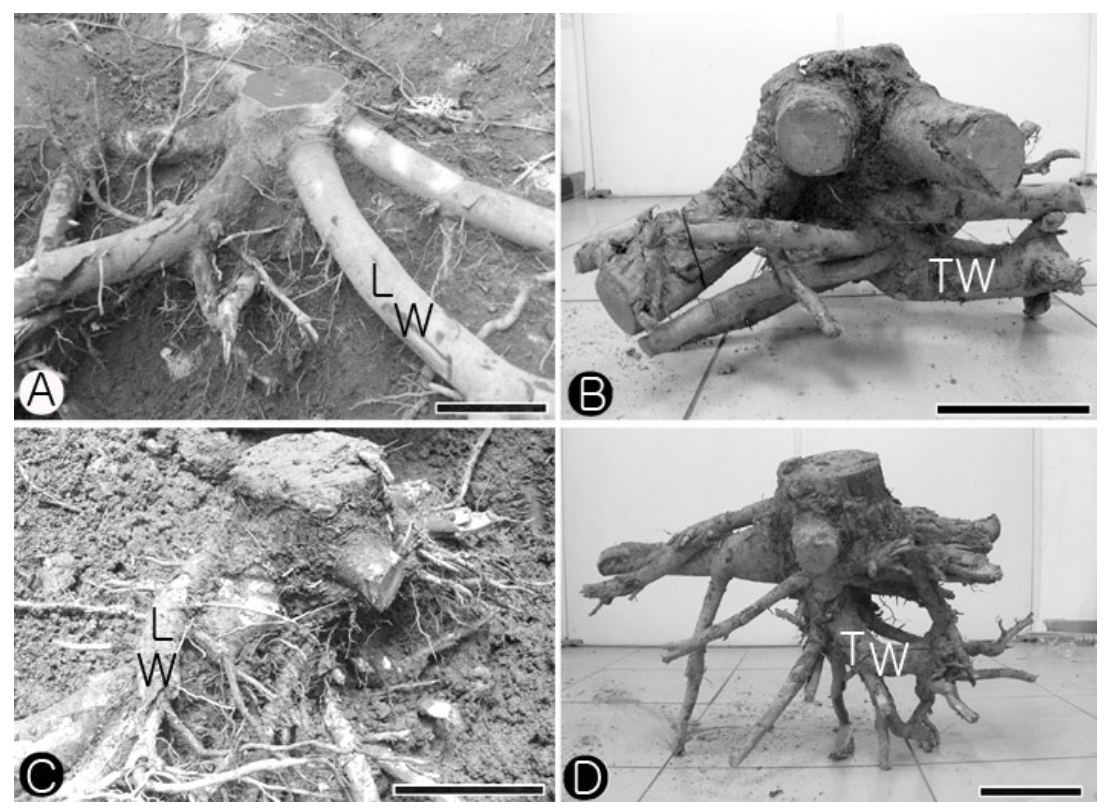

Fig. 1. Photographs showing root samples used in present study. A \& C: before excavation. B \& D: after excavation. TW: tap root wood. LW: lateral root wood. Scale bars $=15 \mathrm{~cm}$ in A \& B; $13 \mathrm{~cm}$ in C \& D.

lar trees (Fig. 1) were obtained from the Korea Forest Research Institute Experimental Forest located near Eocheon Reservoir, Eocheon-ri, Maesong-myeon, Hwaseong-si, Gyeonggi-do, Korea. Discs of about $2 \mathrm{~cm}$ thick were taken from stems at $20 \mathrm{~cm}$ above the soil surface, tap roots at 26 and $36 \mathrm{~cm}$ below the soil surface, and lateral roots at 7 and $10 \mathrm{~cm}$ below the soil surface, respectively.

\subsection{Methods}

Small wood blocks of about 1 to $2 \mathrm{~cm}$ per side cut from the prepared discs were softened in water in an autoclave for 1 to 2 hours and kept in a mixture of water, $99 \%$ ethanol, and glycerine $(1: 1: 1, \mathrm{v} / \mathrm{v} / \mathrm{v})$ for a week or longer.

To investigate qualitative and quantitative wood anatomy, permanent slides and macerations were prepared following general labo- ratory techniques. For permanent slides, sections of 20 to $45 \mu \mathrm{m}$ thick were sliced from transverse, radial, and tangential surface with a sliding microtome and stained with $1 \%$ solution of safranin dissolved in $50 \%$ ethanol for 30 minutes. Then, they were immediately dehydrated in a series of $50,70,90,95,100 \%$ ethanol, a mixture of ethanol and xylene (1: 1 , $\mathrm{v} / \mathrm{v}$ ), and pure xylene for 20 minutes each, followed by mounting with Canada balsam (Kim, 2004; Eom et al., 2008). And macerations were obtained with Schultze's solution consisting of a saturated aqueous solution of potassium chlorate and varying amounts of concentrated nitric acid (Berlyn and Miksche, 1976). Observation, photomicrography, and measurement were made using an Axioskop routine microscope with attachment camera, Carl Zeiss, Germany, a PJ 300 profile projector, Mitutoyo, Japan, and a Camscope video microscope system, Sometech, 

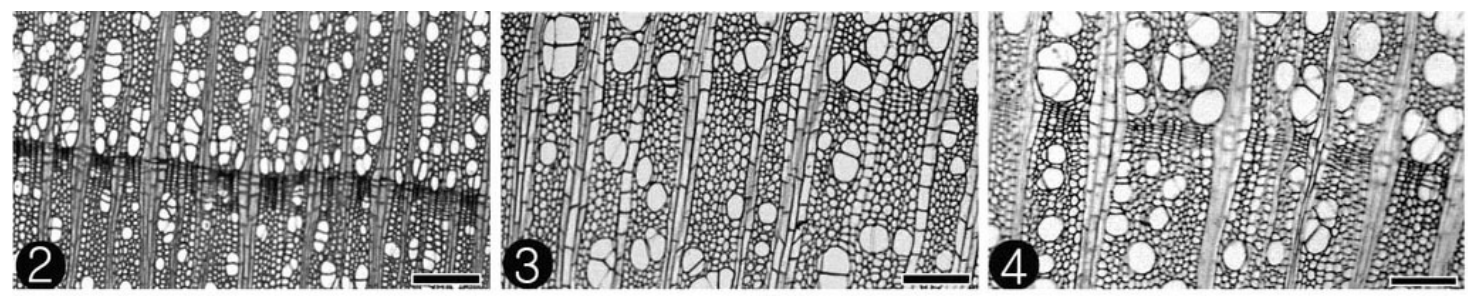

Figs. 2 4. Transverse surfaces showing growth rings distinct (2) to relatively less distinct ( $3 \& 4$ ), axial parenchymas in marginal or seemingly marginal bands at boundaries, and pores solitary, in radial multiples, and clustered $(2 \sim 4)$. 2: stem wood. 3: tap root wood. 4: lateral root wood. Scale bars $=200$ $\mu \mathrm{m}$.

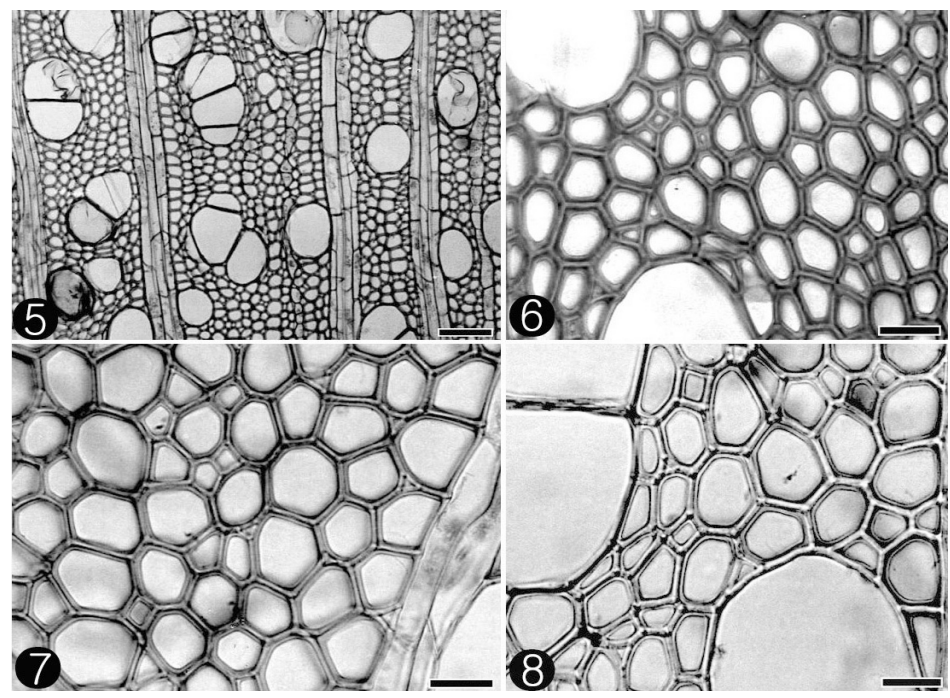

Figs. $5 \sim 8$. Transverse surfaces showing vessel elements with tyloses (5) and thin-walled fibers $(6 \sim 8)$. 5: lateral root wood. 6: stem wood. 7: tap root wood. 8: lateral root wood. Scale bars $=100 \mu \mathrm{m}$ in $5 ; 25$ $\mu \mathrm{m}$ in $6 \sim 8$.

Korea. And all the quantitative measurements followed the recommendations of Wheeler (1986) and IAWA Committee (1989).

In the quantitative analysis, lengths of 50 and diameters of 25 randomly selected wood fibers were measured from macerations. Tangential diameters of vessel lumina were measured from 25 randomly selected solitary pores and pore densities, i.e. numbers of pores or vessels per square millimeter, were counted from pores solitary and in radial multiples on 25 randomly selected fields in transverse surfaces of permanent slides. In case of pores in radial multiples, all pores or vessels counted as individuals, e.g. a radial multiple of four as four pores, were used in the determination of pore density. Lengths of 50 randomly selected vessel elements and numbers of bars in scalariform perforation plates of 25 randomly selected vessel elements were measured from macerations. From permanent slides, ray spacings, i.e. numbers of rays per millimeter along a line perpendicular to 


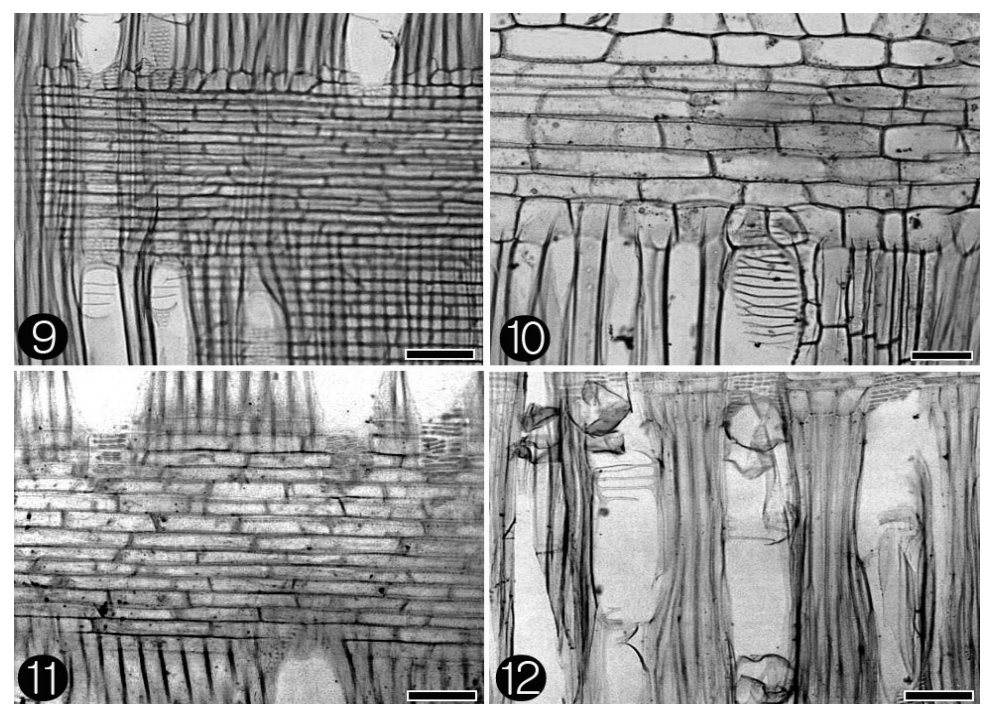

Figs. 9 12. Radial surfaces showing rays homocellular (11) and heterocellular (9 \& 10), and vessel elements with scalariform perforation plates $(9 \& 10)$ and tyloses (12). 9: stem wood. $10 \sim 12$ : lateral root wood. Scale bars $=100 \mu \mathrm{m}$ in $9,11 \& 12 ; 50 \mu \mathrm{m}$ in 10 .

the ray's axis, were counted on 25 randomly selected fields in transverse surfaces, and ray heights and widths both in dimension and cell numbers were measured from 25 randomly selected rays in tangential surfaces. Differences between averages of root wood and stem wood in quantitative features were statistically analysed using Duncan's multiple range test in Statistical Analysis System (SAS).

On the other hand, the contents of holocellulose, lignin, and extractives were determined for comparison of chemical composition between stem wood and root wood. Extractives content was measured using wood powders of 40 mesh size and a mixture of ethanol and benzene $(1: 2, \mathrm{v} / \mathrm{v})$. The extractivesfree wood powders were used for measuring holocellulose content by the use of a mixture of distilled water, acetic acid, and sodium chlorite (75: $0.1: 0.5, \mathrm{v} / \mathrm{v} / \mathrm{w}$ ) and klason lignin content by the use of $72 \%$ sulfuric acid and a 1601-PC UV spectrophotometer, Shimadzu, Japan (Browning,
1967; Japan Wood Research Society, 1985; TAPPI, T222 om-88, 1988; TAPPI T264 om-88, 1988; Joaquim et al., 2009).

\section{RESULTS and DISCUSSION}

\subsection{Qualitative Anatomical Features}

For stem of yellow-poplar, wood is diffuse-porous with distinct growth rings. Pores are mostly solitary and in radial multiples of 2 to 5 but sometimes clustered (Fig. 2). Perforation plates of vessel elements are mostly scalariform but occasionally simple, and intervessel pits are opposite to scalariform (Figs. 9 \& 16). Vessel-ray pits are apparently simple to slightly bordered, rounded to horizontal, and unilaterally compound (Fig. 21). Wood fibers are very thin-walled (Fig. 6) and axial parenchymas are marginal or seemingly marginal at the growth ring boundaries (Fig. 2). Homocellular rays consist of procumbent cells, and heterocellular rays are 

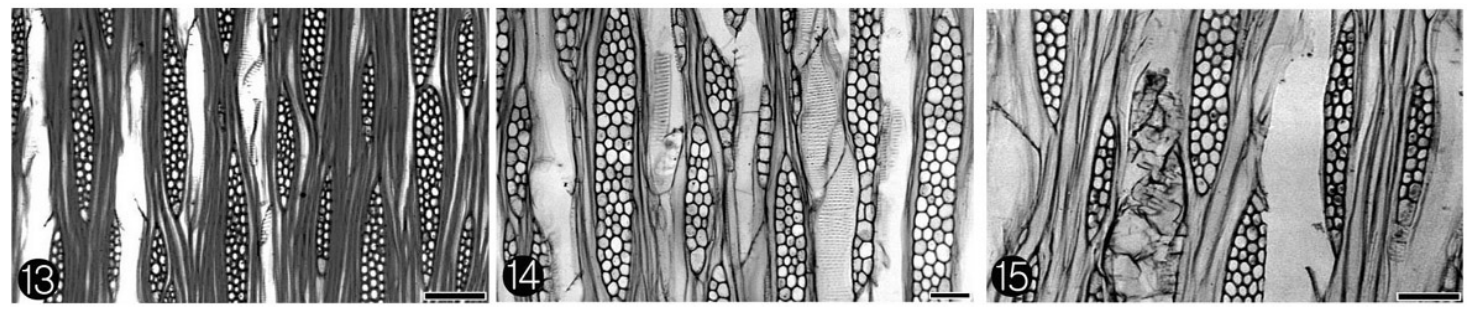

Figs. 13 15. Tangential surfaces showing vessel elements with tyloses (15) and rays mostly multiseriate but occasionally uniseriate or biseriate $(13 \sim 15)$. 13: stem wood. 14: tap root wood. 15: lateral root wood. Scale bars $=100 \mu \mathrm{m}$.
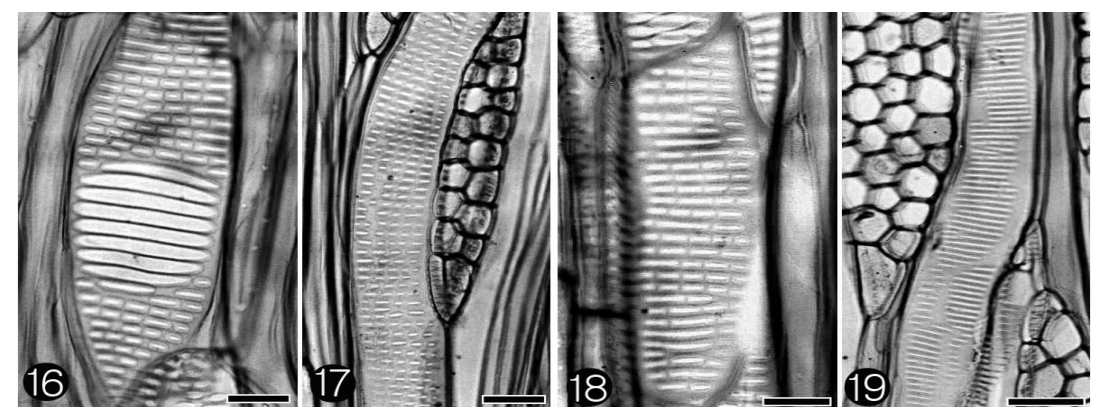

Figs. 16 19. Tangential surfaces showing vessel elements with scalariform perforation plates (16) and intervessel pits opposite to scalariform $(16 \sim 19)$. 16: stem wood. $17 \sim 19$ : tap root wood. Scale bars $=25$ $\mu \mathrm{m}$ in $16 \& 18 ; 50 \mu \mathrm{m}$ in $19 \& 20$.

composed of procumbent body cells and generally 1 to 2 rows of square and/or upright marginal cells (Fig. 9). Rays are mostly multiseriate, occasionally uniseriate or biseriate (Fig. 13). These features of stem wood are generally identical to the descriptions of Panshin and de Zeeuw (1980), IAWA Committee (1989), Hoadley (1990), Itoh (1996), Lee (1997), and Chong and Park (2008).

For root of yellow-poplar, wood is diffuse-porous consisting of solitary and multiple pores as in stem wood. When compared with stem wood, however, root wood shows relatively less distinct growth rings because of smaller differences in pore diameter and less radially flattened or narrower zone of flattened axial parenchyma cells between earlywood and latewood at the boundaries (Figs. $3 \& 4$ ).
Unlike stem wood, also, pores in radial multiples of 2 to 3 are common and pore clusters are rarely observed (Figs. $3 \& 4$ ), and thin-walled tyloses are sometimes present in vessel elements of root wood (Figs. 5, 12 \& 15). Perforation plates of vessel elements are mostly scalariform but occasionally simple and intervessel pits are opposite to scalariform (Figs. 10, 12 \& 17 19), thus identical to those in stem wood. But reticulate perforation plates are occasionally observed only in vessel elements of root wood (Fig. 20). Root wood and stem wood also share common features in vessel-ray pits apparently simple to slightly bordered, rounded to horizontal, and unilaterally compound (Figs. 20, 22 \& 23), wood fibers very thin-walled (Figs. $7 \& 8$ ), axial parenchymas marginal or seemingly marginal at the growth ring boundaries, homo- 


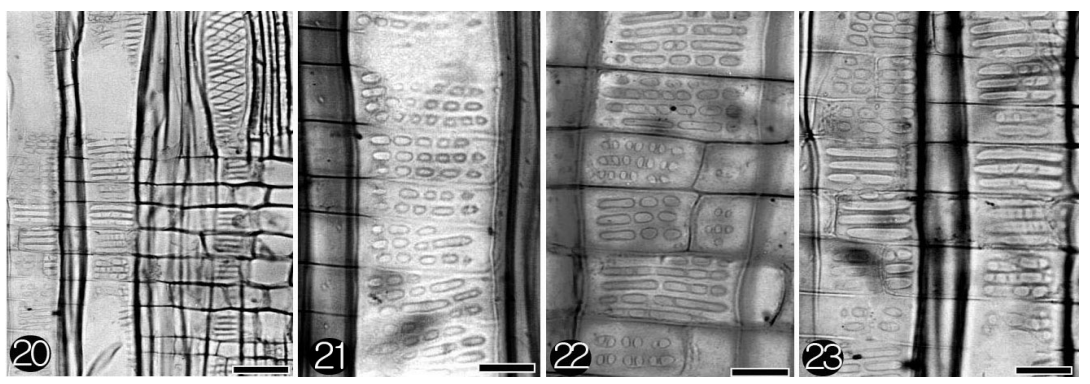

Figs. 20 23. Radial surfaces showing vessel element with reticulate perforation plate (20) and vessel-ray pits apparently simple to slightly bordered, rounded to horizontal, and unilaterally compound $(20 \sim 23)$. $20 \&$ 23: lateral root wood. 21: stem wood. 22: tap root wood. Scale bars $=50 \mu \mathrm{m}$ in $20 ; 25$ $\mu \mathrm{m}$ in $21 \sim 23$.

cellular rays consisting of procumbent cells, heterocellular rays composed of procumbent body cells and generally 1 to 2 rows of square and/or upright marginal cells, and rays mostly multiseriate, occasionally uniseriate or biseriate (Figs. $10,11,14 \& 15)$. Ray parenchyma cells in root wood, however, are generally larger than those in stem wood, thus resulting in considerably higher and wider root wood rays in dimension, rather than in cell numbers (Figs. 14, 15, 31 \& 32, Table 2). Interestingly, extraneous materials are more abundant in wood rays of tap root than in those of stem and lateral root (Figs. 24 $\& 25$, Table 2). The features of root wood are generally identical to the description of Cutler et al. (1987).

Occurrence of relatively less distinct growth rings in root wood than in stem wood in present study is thought be related to the seasonal soil water availability as an important factor affecting the growth ring formation as well as the less probability of growth ring formation due to the uniformity of environmental conditions of the soil (Lebedenko, 1962; Machado et al., 2007). Similarly to the result in present study, Hitz et al. (2008) identified in Fraxinus excelsior that growth rings were usually distinct in stem wood but sometimes hard to distinguish in root wood. And growth rings of Quercus pet- raea were reported to be distinct in stem wood but indistinct in root wood by Schweingruber et al. (2006). In contrast to the result in present study, however, growth rings were found to be distinct by radially flattened fibers in aerial root wood of Sonneratia caseolaris by Rao et al. (1989).

In stem wood of yellow-poplar, vessel elements were known to have thin-walled tyloses by Heiss (2000), Richter and Dallwitz (2000), and Chong and Park (2008). But no tyloses are identified in vessel elements of stem wood in present study, which is thought to be attributed to the young stem wood consisting exclusively of sapwood because tyloses are found most commonly in heartwood vessel elements as described by Panshin and de Zeeuw (1980), IAWA Committee (1989), and Butterfield et al. (2000). Also, vessel elements with tyloses in root wood in present study are in disagreement with Rao et al. (1989) who reported tyloses to be frequent in stem wood but absent in root wood for Sonneratia caseolaris.

Machado et al. (1997) in the comparative wood anatomy of root and stem in Styrax camporum reported that solitary pores were more abundant in root wood than in stem wood, and vessel elements with simple perforation plates and vestured pits, and septate libriform fibers 


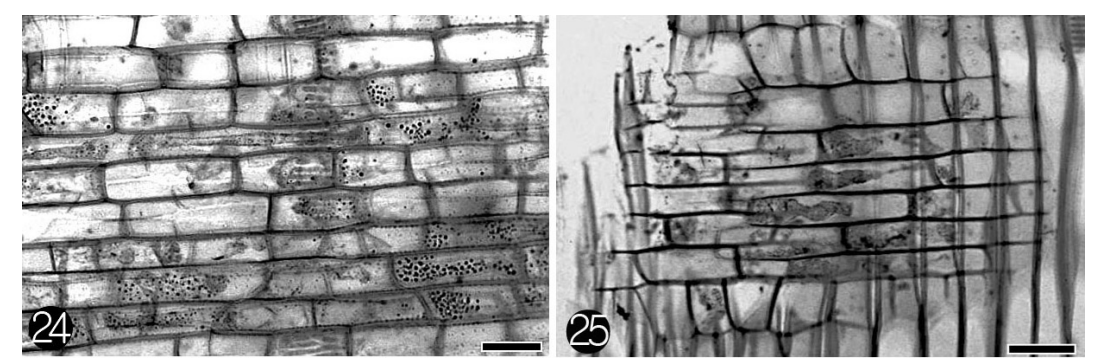

Figs. $24 \& 25$. Radial surfaces showing extraneous materials in ray parenchyma cells in tap root wood. Scale bars $=50 \mu \mathrm{m}$.

were present in root wood but vessel elements with multiple perforation plates and non-vestured pits, and non-septate fiber tracheids in stem wood. Also, they found solitary prismatic crystals to be predominantly present in the ray parenchyma cells in root wood but in the axial parenchyma cells in stem wood.

In the shrub Phlomis fruticosa, Psaras and Sofroniou (2004) found pores to be usually arranged in tangential bands in stem wood but mostly solitary with some radial multiples of 2 in root wood. And Palhares et al. (2007) recorded that maximum diameters of wood fibers were greater in root wood but wall thicknesses of wood fibers were greater in stem wood in Brosimum gaudichaudii.

Goulart and Marcati (2008) noted in vessel elements of Lippia salviifolia that simple and scalariform to reticulate perforation plates were observed in root and stem wood but radiate perforation plates were identified only in root wood, like the presence of simple and scalariform perforation plates in stem and root wood but reticulate perforation plates only in root wood in present study.

As extraneous materials are abundantly observed in wood rays of tap root in present study (Figs. $24 \& 25$ ), reddish brown phenolic compounds were reported to be usually present in rays of root wood for Styrax camporum by Machado et al. (1997) and phenolic compounds to be evident in root wood for Brosimum gaudichaudii by Palhares et al. (2007).

\subsection{Quantitative Anatomical Features}

Quantitative features of stem and root wood are shown in Table 1. Pore densities, i.e. numbers of pores or vessels per square millimeter, average about 76.0 in stem wood, thus broadly agreeing with the result of 72 to 140 in yellow-poplar by Lee (1997). For root wood, average pore densities are 37.4 in tap root and 30.3 in lateral root. Therefore, pore densities appear not to be different between root forms but significantly greater in stem wood than in root wood. This is in agreement with Psaras and Sofroniou (1999) who reported in Capparis spinosa that pore densities were considerably greater in stem wood than in root wood. In contrast to the result in present study, however, Rao et al. (1989) found in Sonneratia caseolaris pore densities to be significantly fewer in stem wood than in root wood. Machado et al. (2007) in Styrax indicated that pore densities in stem wood were generally greater than in root wood in $S$. camporum and S. ferrugineus but were not different between root wood and stem wood in S. latifolium and S. martii. No significant differences in pore densities, on the other hand, were identified between root wood and stem wood in Phlomis fruticosa and Brosi- 
Table 1. Quantitative anatomical features of stem and root wood

\begin{tabular}{lccc}
\hline \multicolumn{1}{c}{ Anatomical features } & Stem wood & Tap root wood & Lateral root wood \\
\hline \hline Vessel elements & & & \\
Pore density $\left(\right.$ no. $\left./ \mathrm{mm}^{2}\right)$ & $76.0(9.54) \mathrm{A}$ & $37.4(8.10) \mathrm{B}$ & $30.3(6.82) \mathrm{C}$ \\
Tangential diameter $(\mu \mathrm{m})$ & $64.0(7.19) \mathrm{A}$ & $89.0(13.83) \mathrm{B}$ & $99.1(11.95) \mathrm{C}$ \\
Length $(\mu \mathrm{m})$ & $513.8(109.07) \mathrm{A}$ & $741.9(132.94) \mathrm{B}$ & $715.8(155.55) \mathrm{B}$ \\
Bar $($ no. per scalariform perforation plate) & $5.50(1.82) \mathrm{A}$ & $7.36(2.10) \mathrm{B}$ & $6.38(1.94) \mathrm{C}$ \\
Rays & & & \\
Spacing $($ no. $/ \mathrm{mm})$ & $7.7(1.17) \mathrm{A}$ & $5.0(1.00) \mathrm{B}$ & $5.0(1.03) \mathrm{B}$ \\
Width $($ no. of cells) & $3.6(0.61) \mathrm{A}$ & $3.7(0.62) \mathrm{A}$ & $4.1(1.07) \mathrm{B}$ \\
Width $(\mu \mathrm{m})$ & $43.4(8.23) \mathrm{A}$ & $75.6(17.93) \mathrm{B}$ & $70.3(17.76) \mathrm{B}$ \\
Height $(\mathrm{no}$. of cells) & $27.6(11.00) \mathrm{A}$ & $20.3(6.81) \mathrm{B}$ & $23.9(9.32) \mathrm{B}$ \\
Height $(\mu \mathrm{m})$ & $440.9(170.08) \mathrm{A}$ & $584.1(210.35) \mathrm{B}$ & $634.1(280.88) \mathrm{B}$ \\
Wood fibers & & & \\
Length $(\mu \mathrm{m})$ & $1212.9(208.64) \mathrm{A}$ & $1480.8(266.89) \mathrm{B}$ & $1535.5(217.17) \mathrm{B}$ \\
Diameter $(\mu \mathrm{m})$ & $27.8(4.52) \mathrm{A}$ & $37.0(5.89) \mathrm{B}$ & $38.6(6.75) \mathrm{B}$ \\
\hline Aves $( \pm \mathrm{stan}$
\end{tabular}

Averages ( \pm standard deviation) followed by the same letter in each feature are not significantly different at a confidence level of $99 \%$.

mum gaudichaudii by Psaras and Sofroniou (2004) and Palhares et al. (2007), respectively.

Average tangential diameters of vessel elements in stem wood are $64.0 \mu \mathrm{m}$, thus generally agreeing with the results of 30 to $70 \mu \mathrm{m}$ in yellow-poplar by Lee (1997) and $67 \mu \mathrm{m}$ by Ryu et al. (2008). For root wood, tangential diameters of vessel elements are $89.0 \mu \mathrm{m}$ in tap root and $99.1 \mu \mathrm{m}$ in lateral root. Contrary to the result of pore densities, in present study, vessel elements appear to be significantly wider in root wood than in stem wood. This is in agreement with Psaras and Sofroniou (1999, 2004) and Schwe- ingruber et al. (2006) who descried that big vessels were characteristic of root wood but small vessels were typical of stem wood in Capparis spinosa, Fagus sylvatica, Phlomis fruticosa, Ziziphus lotus. Rao et al. (1989), however, indicated that vessel elements of stem wood were greater in tangential diameters than those of root wood in Sonneratia caseolaris. On the other hand, Machado et al. (1997, 2007) noted in Styrax that tangential diameters of vessel elements in root wood were generally greater than those in stem wood in S. camporum and S. ferrugineus and vice versa in S. latifolium and S. martii. By Palhares et al. (2007), no significant differences in tangential diameters of vessel elements between stem and root wood were reported in Brosimum gaudichaudii. Ewers et al. (1997) noted significantly wider vessel elements in root wood than in stem wood for Fabaceae trees and shrubs and vice versa for Fabaceae lianas. In present study, greater pore densities in stem wood than in root wood were thought to be able to partially compensate for their narrower tangential diameters.

Lengths of vessel elements, on the average, are $513.8 \mu \mathrm{m}$ in stem wood, $741.9 \mu \mathrm{m}$ in tap root wood, and $715.8 \mu \mathrm{m}$ in lateral root wood, which means that they are not different between root forms but are significantly greater in root 
wood than in stem wood. This agrees with Psaras and Sofroniou (1999, 2004) who reported that vessel elements were longer in root wood than in stem wood for Capparis spinosa and Phlomis fruticosa. Contrary to the result in present study, however, Rao et al. (1989) found the vessel elements of stem wood to be longer than those of root wood in Sonneratia caseolaris. On the other hand, Machado et al. (2007) reported in Styrax that vessel elements of root wood were generally longer than those of stem wood in S. martii and S. ferrugineus and vice versa in S. latifolium, S. leprosus, and S. camporum.

For scalariform perforation plates of vessel elements, average bar numbers are 7.36 in tap root wood, 6.38 in lateral root wood, and 5.50 in stem wood, and thus the bar numbers appear to be greater in root wood than in stem wood. In Styrax camporum, Machado et al. (1997) found vessel elements with simple perforation plates to be predominant in root wood but those with scalariform perforation plates to be predominant in stem wood.

Average lengths and widths of wood fibers are 1212.9 and $27.8 \mu \mathrm{m}$ in stem, 1480.8 and $37.0 \mu \mathrm{m}$ in tap root, and 1535.5 and $38.6 \mu \mathrm{m}$ in lateral root. Like vessel element dimensions in present study, wood fiber lengths and widths are not different between root forms but greater in root wood than in stem wood. This in agreement with the results of Psaras and Sofroniou $(1999,2004)$ who reported that wood fibers of root wood were longer than those of stem wood in Capparis spinosa and Phlomis fruticosa and Palhares et al. (2007) who recorded that wood fibers of root wood were wider than those of stem wood in Brosimum gaudichaudii. On the other hand, Machado et al. (1997, 2007) noted in Styrax that wood fibers of stem wood were slightly narrower than those of root wood in all the species examined, but more or less longer than those of root wood in S. latifolium, $S$. martii, and $S$. leprosus and vice versa in $S$. camporum and $S$. ferrugineus. In yellow-poplar, wood fiber lengths of stem wood were recorded as 860 to $1,490 \mu \mathrm{m}$ by Lee (1997) and 870 to $1,540 \mu \mathrm{m}$ by Ryu et al. (2008).

Ray spacings, i.e. numbers of rays per millimeter along a line perpendicular to the ray's axis, average 7.7 in stem wood, 5.0 both in the tap root wood and lateral root wood, which means that rays are somewhat numerous in stem wood than in root wood. In stem wood of yellow-poplar, ray spacing was reported as 5.0 by Ryu et al. (2008). In contrast to the result in present study, Psaras and Sofroniou (1999, 2004) reported that ray spacings were identical between root wood and stem wood in Capparis spinosa but somewhat greater in root wood than in stem wood for Phlomis fruticosa. On the other hand, Machado et al. (1997, 2007) recorded in Styrax that ray spacings were lower in root wood than in stem wood for $S$. leprosus, $S$. camporum, and $S$. ferrugineus but were not different between them for $S$. latifolium and $S$. martii.

Ray sizes average 3.6 cells wide and 27.6 cells high in stem wood, 3.7 cells wide and 20.3 cells high in tap root wood, and 4.1 cells wide and 23.9 cells high in lateral root wood, respectively. This indicates that ray heights in cell numbers are greater in stem wood than in root wood but ray widths in cell numbers are not significantly different from each other. Contrary to the result in present study, Rao et al. (1989) found the ray heights in cell numbers to be somewhat greater in root wood than in stem wood in Sonneratia caseolaris. Ray heights and widths in dimension, however, average 440.9 and $43.4 \mu \mathrm{m}$ in stem wood, 584.1 and $75.6 \mu \mathrm{m}$ in tap root wood, and 634.1 and $70.3 \mu \mathrm{m}$ in lateral root wood, respectively. Therefore, rays of root wood appear to be di- 
Mi Rim Lee and Young Geun Eom

Table 2. Chemical constituents in stem and root wood

\begin{tabular}{ccccc}
\hline Part & Holocellulose & Klason lignin & Extractives & Total \\
\hline \hline Stem wood & $78.8 \%(76.2 \%)$ & $22.8 \%(22.0 \%)$ & $1.9 \%(1.8 \%)$ & $103.5 \%(100.0 \%)$ \\
Tap root wood & $72.4 \%(74.6 \%)$ & $20.9 \%(21.5 \%)$ & $3.8 \%(3.9 \%)$ & $97.1 \%(100.0 \%)$ \\
Lateral root wood & $78.6 \%(75.7 \%)$ & $23.4 \%(22.6 \%)$ & $1.8 \%(1.7 \%)$ & $103.8 \%(100.0 \%)$ \\
\hline
\end{tabular}

Values in parentheses are based on adjusting the sum of percentages to $100 \%$.

mensionally greater in height and width than those of stem wood (Figs. 13 15). This is in agreement with Psaras and Sofroniou (2004) and Palhares et al. (2007) who recorded in Phlomis fruticosa and Brosimum gaudichaudii that ray heights in dimension were somewhat greater in root wood than in stem wood. In Capparis spinosa, however, rays in dimension were known to be very significantly greater in stem wood than in root wood by Psaras and Sofroniou (1999). On the other hand, multiseriate ray widths in dimension were found to be identical between root wood and stem wood for Phlomis fruticosa by Psaras and Sofroniou (2004) but to be greater in root wood than in stem wood for Capparis spinosa and Brosimum gaudichaudii by Psaras and Sofroniou (1999) and Palhares et al. (2007). In contrast to the result in present study, Palhares et al. (2007) noted that ray heights and widths in cell numbers were not different between stem wood and root wood for Brosimum gaudichaudii. On the other hand, Machado et al. (2007) found ray heights to be dimensionally greater in root wood than in stem wood for $S$. camporum and $S$. ferrugineus but ray widths to be dimensionally greater in root wood than in stem wood for $S$. latifolium, $S$. martii, S. leprosus, and S. camporum.

These qualitative and quantitative differences in wood anatomy between stem and root are thought to be associated with the opinions of Timell (1986), Schweingruber et al. (2006) and Bowyer et al. (2007) who described that wood anatomical differences between stem above ground and root below ground were recogniz- able within a tree because of their different growth environments like photomorphogenetic stimulus.

\subsection{Chemical Characteristics}

Wood chemical constituents of stem and root in yellow-poplar are shown in Table 2. Holocellulose and klason lignin contents, on the average, are approximately 78.8 and $22.8 \%$ in stem wood, 72.4 and $20.9 \%$ in tap root wood, and 78.6 and $23.4 \%$ in lateral root wood, respectively. Thus, their contents appear to be lower in tap root wood than in stem wood and lateral root wood. In stem wood of yellow-poplar, the respective contents of holocellulose and klason lignin were previously recorded as 72.7 and $23.44 \%$ by Han (1982).

Extractives contents average $1.9 \%$ in stem wood, $3.8 \%$ in tap root wood, and $1.8 \%$ in lateral root wood, thus identical to the anatomical observation of more extraneous materials in wood rays of tap root than in those of stem and lateral root (Figs. $24 \& 25)$. When considering the opinions of Magel et al. (1994) and Burtin et al. (1998) that extractives were synthesized from the breakdown of starch or from soluble sugars, occurrence of more extraneous materials in wood rays of tap root in present study is thought to be somewhat related to the observations that reddish brown phenolic compounds usually present in rays of root wood for Styrax camporum by Machado et al. (1997) and starch grains commonly found in root wood but not in stem wood as well as phenolic com- 
pounds evident in root wood for Brosimum gaudichaudii by Palhares et al. (2007), respectively. Like the earlier reports of Braun (1984), Carlquist (1985), and Lindorf (1997), on the other hand, abundant starch grains in ray parenchyma cells of Capparis spinosa were considered as deposits of temporary osmotically inactive surplus carbohydrates by Psaras and Sofroniou (1999). And Howard (1973) and Bowyer et al. (2007) stated in Pinus elliottii that cellulose content was lower with lignin and extractives contents correspondingly higher in root than in stem.

\section{CONCLUSIONS}

Stem wood and root wood in yellow-poplar (Liriodendron tulipifera L.) were described and compared in the qualitative and quantitative anatomical aspects. In the qualitative features, growth rings were distinct in stem wood but relatively less distinct in root wood. And stem wood appeared to have pores in radial multiples of 2 to 5 , sometimes in clusters but root wood to have pores in radial multiples of 2 to 3 , rarely in clusters. And numbers of bars in scalariform perforation plates were somewhat numerous in vessel elements of root wood than in those of stem wood. Interestingly, on the other hand, more extraneous materials in the wood rays of tap root than in those of lateral root and stem were confirmed in the chemical composition analyses. In the quantitative features, pore densities were significantly greater but vessel elements were considerably narrower in stem wood than in root wood. Vessel elements and wood fibers of root wood were considerably longer than those of stem wood. Rays were somewhat more numerous in stem wood than in root wood, and only ray heights of stem wood were more or less greater in cell numbers but both ray heights and widths of stem wood were lower in dimension than those of root wood.

\section{REFERENCES}

1. Berlyn, G. P. and J. P. Miksche. 1976. Botanical microtechnique and cytochemistry. Iowa State Univ. Press, Iowa.

2. Bowyer, J. L., R. Shmulski, and J. G. Haygreen. 2007. Forest products and wood science: An introduction. 5th ed., Blackwell Publishing, Iowa.

3. Braun, H. J. 1984. The significance of the accessory tissues of the hydrosystem for osmotic water shifting as the second principle of water ascent, with some thoughts concerning the evolution of trees. IAWA Bull. n.s. 5: 275 294 .

4. Browning, B. L. 1967. Methods of wood chemistry. Interscience Publishers, New York.

5. Burtin, P., C. Jay-Allemand, J. P. Charpentierand, and G. Janin. 1998. Natural wood colouring process in Juglans sp. ( $J$. nigra, J. regia and hybrid $J$. nigra $\times J$. regia) depends on native phenolic compounds accumulated in the transition zone between sapwood and heartwood. Trees 12: 258 264.

6. Butterfield, B. G., B. A. Meylan, and Y. G. Eom. 2000. Three dimensional structure of wood. WIT Consulting, Seoul.

7. Carlquist, S. 1985. Observations on functional wood histology of vines and lianas: Vessel dimorphism, tracheids, vasicentric tracheids, narrow vessels, and parenchyma. Aliso 11: 139 157.

8. Chong, S. H. and B. S. Park. 2008. Wood properties of the useful tree species grown in Korea. New Research Book No. 29, Korea Forest Research Institute, Seoul.

9. Cutler, D. F., P. J. Rudall, P. E. Gasson, and R. M. O. Gale. 1987. Root identification manual of trees and shrubs: A guide to the anatomy of roots of trees and shrubs hardy in Britain and Northern Europe. Chapman and Hall, London.

10. Eom, Y. G., O. Kwon, R. B. Hanna, and R. W. Meyer. 2008. Anatomical comparison of North American eastern, southern, and western redcedar wood. Mokchae Konghak 36(2): 9 19.

11. Ewers, F. W., M. R. Carlton, J. B. Fisher, K. J. 
Kolb, and M. T. Tyree. 1997. Vessel diameters in roots versus stems of tropical lianas and other growth forms. IAWA J. 18(3): $261 \sim 279$.

12. Fahn, A. 1990. Plant anatomy. 4th ed., Pergamon Press, Oxford.

13. Goulart, S. L. and C. R. Marcati. 2008. Anatomia comparada do lenho em raiz e caule de Lippia salviifolia Cham. (Verbenaceae). Revista Brasil. Bot. 31(2): 263 275.

14. Han, C. S. 1982. Studies on the properties of tulip tree (Liriodendron tulipifera L.). III. Analysis of chemical composition. Agr. and Life Sci. Res. 13: 73 78. Inst. Agr. Sci. Tech., Chonbuk National Univ., Jeonju.

15. Heiss, A. G. 2000 onwards. Anatomy of European and North American woods: An interactive identification key. Version: 14th May 2009. http://www. holzanatomie.at. Accessed December 2010.

16. Hitz, O. M., H. Gärtner, I. Heinrich, and M. Monbaron. 2008. Wood anatomical changes in roots of European ash (Fraxinus excelsior L.) after exposure. Dendrochronologia 25: 145 152.

17. Hoadley, R. B. 1990. Identifying wood: Accurate results with simple tools. Taunton Press, Newtown.

18. Howard, E. T. 1973. Physical and chemical properties of slash pine parts. Wood Sci. 5(4): 312 317.

19. IAWA Committee. 1989. IAWA list of microscopic features for hardwood identification. IAWA Bull. n. s. 10(3): $219 \sim 332$.

20. Itoh, T. 1996. Anatomical description of Japanese hardwoods II. Wood Research and Technical Notes No. 3266-176. Wood Research Institute, Kyoto Univ., Kyoto.

21. Japan Wood Research Society. 1985. Wood science laboratory book. II. Chemistry. Chugai Sangyo Chosakai, Tokyo.

22. Joaquim, A. P., G. H. D. Tonoli, S. F. dos Santos, and H. Savastano Jr. 2009. Sisal organosolv pulp as reinforcement for cement based composites. Materials Research 12(3): 305 314.

23. Kim, H. S. 2004. Microscopic patterns of decay caused by Tyromyces palustris and Gloeophyllum trabeum in Korean red pine and radiata pine wood. M. S. Thesis, Graduate School, Kookmin Univ., Seoul.

24. Lebedenko, L. A. 1962. Comparative anatomical analysis of the mature wood of roots and stems of some wood plants. Trudy Inst. Lesa i Drevesiny Akad. Nauk SSSR (Sib. Otdel.) 51: 124 134.

25. Lee, P. W. 1997. Properties and uses of Korean woods. I. Wood structures, properties, and uses. Seoul National Univ. Press, Seoul.

26. Lindorf, H. 1997. Wood and leaf anatomy in Sessea corymbiflora from an eco-logical perspective. IAWA J. 18: 157 168 .

27. Machado, S. R., V. Angyalossy-Alfonso, and B. L. de Morretes. 1997. Comparative wood anatomy of root and stem in Styrax camporum (Styracaceae). IAWA J. 18(1): 13 25.

28. Machado, S. R., R. A. Rodella, V. Anryalossy, and C. R. Marcati. 2007. Structural variations in root and stem wood of Styrax (Styracaceae) from Brazilian forest and Cerrado. IAWA J. 28(2): 173 $\sim 188$.

29. Magel, E., C. Jay-Allemend, and H. Ziegler. 1994. Formation of heartwood substances in the stemwood of Robinia pseudoacacia L.: II. Distribution of non-structural carbohydrates and wood extractives across the trunk. Trees 8: 165-171.

30. Palhares, D., J. E. de Paula, L. A. Rodrigues Pereira, and C. E. dos Santos Silveira. 2007. Comparative wood anatomy of stem, root and xylopodium of Brosimum gaudichaudii (Moraceae). IAWA J. 28(1): 83 94 .

31. Panshin, A. J. and C. de Zeeuw. 1980. Textbook of wood technology. 4th ed., McGraw-Hill Book Co., New York.

32. Psaras, G. K. and I. Sofroniou. 1999. Wood anatomy of Capparis spinosa from an ecological prespective. IAWA J. 20(4): 419 429.

33. Psaras, G. K. and I. Sofroniou. 2004. Stem and root anatomy of the shrub Phlomis fruticosa (Labiatae). IAWA J. 25(1): 71 77.

34. Richter, H. G. and M. J. Dallwitz. 2000 onwards. Commercial timbers: Descriptions, illustrations, identification, and information retrieval. Version: 25th June 2009. http://delta-intkey.com. Accessed December 2010.

35. Rao, R. V., B. Sharma, and R. Dayal. 1989. Anatomy of aerial rootwood of Sonneratia caseolaris (L.) Engler (Sonneratioideae). IAWA Bull. n. s. $10(4): 374 \sim 378$. 
Comparative Wood Anatomy of Stem and Root in Korean-grown Yellow-poplar (Liriodendron tulipipfera L.)

36. Ryu, K. O., W. J. Kim, I. S. Kim, H. S. Choi, D. H. Lee, and Y. W. Kim. 2008. Yellow-poplar (Liriodendron tulipifera L.): Growth characteristics and utilization technology. Research Report No. 320, Korea Forest Research Institute, Seoul.

37. Schweingruber, F. H., A. Börner, and E.-D. Schulze. 2006. Atlas of woody plants: Evolution, structure, and environmental modifications. Springer, Jena.

38. Stokke, D. D. and F. G. Manwiller. 1994. Proportions of wood elements in stem, branch, and root wood of black oak (Quercus velutina).
IAWA J. 15(3): 301 310.

39. TAPPI T222 om-88. 1988. Acid-insoluble lignin in wood and pulp. Atlanta, GA, USA: Technical Association of the Pulp and Paper Industry.

40. TAPPI T264 om-88. 1988. Preparation of wood for chemical analysis. Atlanta, GA, USA: Technical Association of the Pulp and Paper Industry.

41. Timell, T. E. 1986. Compression wood in gymnosperms. Vols. 1-3. Springer-Veralg, Berlin.

42. Wheeler, E. A. 1986. Vessels per square millimeter or vessel groups per square millimeter? IAWA Bull. n. s. 7(1): 73 74. 